\title{
Áhrif sílans og ljósherðingar á viðgerðarstyrk plastblendis
}

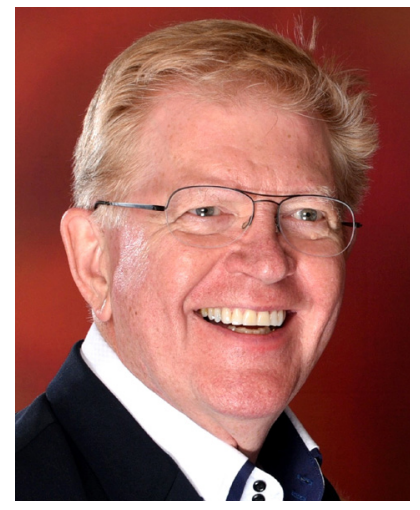

SIGFÚS PÓR ELÍASSONS, CAND. ODONT., MSD, PRÓFESSOR EMERITUS,

TANNL/EKNADEILD HÁSKÓLA ÍSLANDS, GESTAVÍSINDAMAĐUR, NIOM, ÓSLÓ, NOREGI.

JON E. DAHL, CAND. ODONT., DR. ODONT, FORSTÖĐUMAĐUR NIOM, PRÓFESSOR, TANNLAEKNADEILD HÁSKÓLANS Í ÓSLÓ, NOREGI.

TENGILIĐUR: SIGFÚS PÓR ELÍASSONS, sigfuse@hi.is

TANNL/EKNABLAĐIĐ 2021; 39(2): 12-21

doi:10.33112/tann.39.2.1

\section{ÁGRIP}

Tilgangur: Að mæla $\mu$-togpols viðgerðarstyrk milli gamlaðs og nýs plastblendis með pví að nota sílan og mismunandi bindiefni sem voru hert eða óhert pegar nýju plastblendi var bætt við.

Efni og aðferðir: Áttatíu Filtek Supreme XLT plastblendi kubbar og fjórir viðmiðskubbar voru geymdir í vatni í 2 vikur og hitaðir/ kældir 5000x. Kubbarnir voru sandpappírs slípaðir, ætaðir og skolaðir og skipt í tvo hópa: A: óbreytt yfirborð, B: bis-sílan borið á yfirborð. Báðum hópum var síðan skipt í undirhópa: (1) Adper Scotchbond Multi-Purpose, (2) Adper Scotchbond Multi-Purpose Adhesive, (3) Adper Scotchbond Universal, (4) Clearfil SE Bond og (5) One Step Plus. Hverjum bindiefnishóp var síðan skipt í: (a) ljóshert skv. ráðleggingum framleiðanda. (b) ekki hert fyrir viðgerð. Kubbarnir voru síðan viðgerðir með Filtek Supreme XLT. Eftir gömlun í sex mánuði, voru kubbarnir raðskornir i 1,1x1,1 $\mathrm{mm}$. stauta sem voru $\mu$-togpolsprófaðir og viðgerðarstyrkur reiknaður. Brotfletir voru skoðaðir i smásjá og tegund brots skráð.

Niðurstöður: Með pví að herða ekki bindiefnið áður en viðgerð fer fram, jókst bindistyrkur marktækt hjá öllum tegundum bindiefna, með eða án sílans. Sílan meðferð jók bindistyrk marktækt hjá öllum bindiefnum, bæði í hertum og óhertum hópum ( $p<0.001)$. Togstyrkur viðmiðunar plastblendisins var marktækt hærri en hjá sterkasta viðgerðarhópnum ( $p<0.001)$.

Ályktun: Bindistyrkur jókst með pví að herða ekki bindiefnið áður en gert er við með nýju plastblendi. Sílan meðferð og bindiefni sem gaf punnt bindilag höfðu besta viðgerðarstyrkinn.

Lykilorð: sílan, tannbeinsbindiefni, míkró-togpolspróf, plastblendi 


\section{Inngangur}

Sú hugmyndafræði að lagfæra eða gera við gamlar fyllingar hefur verið að ryðja sér til rúms í flestum tannlæknaskólum og meðal tannlækna á Vesturlöndum (1-4). I nýlegri rannsókn meðal norskra tannlækna kom í ljós að átta af hverjum níu tannlæknum velja fremur að gera við smávægilega bilaðar fyllingar en skipta út allri fyllingunni (5).

pegar gert er við gamlar fyllingar, getur nýtt plastbendi bundist gömlu með undirskurði í gamla plastið auk pess sem pað getur sest i gróft yfirborð. Einnig getur pað bundist efnafræðilega við fyllikorn og lífrænan hluta plasblendis, pótt styrkleiki pess síðara minnki verulega með tímanum (6-9). Prátt fyrir að engar langtíma klínískar rannsóknir hafi farið fram á viðgerðum bilaðra plastblendifyllinga, eru vaxandi vísbendingar á að viðgerðin auki marktækt líftíma fyllinganna $(10,11)$. Vísindamenn hafa aftur á móti kannað aðferðir við að bæta nýju plastblendi við gamalt (12). Langflestar pessara rannsókna ganga út á að mæla in-vitro áhrif mismunandi plastblendi límtegunda og yfirborðsmeðferða á gömluðu plastblendi á bindingu við nýtt plastblendi. pessar yfirborðsmeðferðir eru, auk pess að gera yfirborðið hrjúft með mismunandi grófum demantsborum, sandblástur með mismunandi efnum, æting með flússsýru, laser- og sílanmeðferð. Klínísk hagkvæmni sumra pessara yfirborðsmeðferða er mjög vafasöm vegna pess tíma sem parf, tækjabúnaðar og öryggis sjúklinga. Ekki hefur myndast einhugur meðal vísindamanna og tannlækna um heppilegustu aðferðina (12).

Í fyrri rannsókn höfunda kom í ljós að viðgerðar- eða bindistyrkur milli gamals og nýs plasblendis jókst mjög marktækt ef gamla plstblendið var sílanborið (13). Niðurstöður margra annarra rannsókna styðja pessar niðurstöður meðan aðrar merkja ekki mun (4-21).
Vegna bykktar og lítillar bleytigetu plastblendis hefur tannbeinsbindiefni verið notað sem bleytiefni til að auka bindingu milli gamals og nýs plastblendis $(22,23)$. Lægri mikro-togbindistyrkur mældist með Single Bond (3M ESPE) eftir pví sem fleiri lög af bindiefni voru notuð, pegar gamalt plastblendi var viðgert með nýju, meðan ómarktækur munur mældist milli fjölda laga pegar Clearfil (Kuraray) var notað, en pað er mjög punnfljótandi (24). Dall'Oca et al. hafa haldið pví fram að samskeyti milli gamla og nýja plastblendis séu alltaf veikasti hlekkurinn pegar gert er við plastblendi fyllingu (25). Pað er pví æskilegt að minnka pykkt bindilags eins og kostur er. Í fyrri rannsókn höfunda fannst að viðgerðarstyrkur jókst eftir pví sem bindilag mældist pynnra (13). Með pví að pynna bindilag enn frekar, gæti hugsanlega nást ennpá sterkari binding milli gamals og nýs plastblendis.

Aðal tilgangur pessarar rannsóknar var að mæla með mikro-togpolsprófi viðgerðarstyrk gamlaðs og nýs plastblendis með pví að nota mismunandi tannbeinsbindiefni sem voru annað hvort hert samkvæmt ráðleggingum framleiðanda, eða haft óhert pegar nýju plastblendi var bætt við pað gamla. Einnig að mæla áhrif sílans yfirborðsmeðferðar með míkró-togpolsprófi á viðgerðarstyrk milli gamlaðs og nýs plastblendis. Núlltilgátur sem prófaðar voru: 1. Viðgerðarstyrkur er óháđur pví hvort tannbeinsbindiefni er ljóshert eða ekki, áður en nýju plastblendi er bætt við pað gamlaða. 2. Viðgerðarstyrkur er óháður sílanmeðferð á gamlað plastblendi. 3. Viðgerðarstyrkur er óháður pví hvaða tannbeinsbindiefni er notað.

Tafla 1. Plastblendi og bindiefni sem voru notuð i rannsókninni.

\begin{tabular}{|l|l|l|}
\hline \multicolumn{1}{|c|}{ Efni } & \multicolumn{1}{|c|}{ Framleidandi } \\
\hline Filtek Supreme XTE litur A1B & 3M ESPE Dental Products St. Paul, MN 55144-1000, USA & $\begin{array}{l}\text { N513137 } \\
\text { N535292 }\end{array}$ \\
\hline Filtek Supreme XTE litur A3,5B & 3M ESPE Dental Products St. Paul, MN 55144-1000, USA & N499574 \\
\hline Adper Scotchbond Multy-Purpose & 3M ESPE Dental Products St. Paul, MN 55144-1000, USA & N520758 \\
\hline $\begin{array}{l}\text { Adper Scotchbond Universal } \\
\text { Adhesive }\end{array}$ & M ESPE Dental Products St. Paul, MN 55144-1000, USA & 532089 \\
\hline Clearfil SE Bond & Kuraray America, Inc. New York, NY 10038, USA & 000039 \\
\hline One Step & BISCO, Inc., Schaumburg, IL 60193, USA & 1400001552 \\
\hline Bis-Silane & BISCO, Inc., Schaumburg, IL 60193, USA & 1300001356 \\
\hline
\end{tabular}


Tafla 2. Yfirlit yfir gerð, uppbyggingu og meðferð plastblendi sýna

\begin{tabular}{|c|c|c|c|c|c|c|c|c|c|c|c|c|c|c|c|c|c|c|c|c|c|}
\hline Grunn sýni & \multicolumn{20}{|c|}{ Filtek Supreme XLT litur A1B (10 x 6.2 × 8 mm) } & $\begin{array}{c}(10 \times 6.2 \times \\
12 \mathrm{~mm})\end{array}$ \\
\hline Aðal hópar & \multicolumn{10}{|c|}{ A } & \multicolumn{10}{|c|}{$B$} & C Viðmið \\
\hline $\begin{array}{l}\text { Gömlun } \\
\text { (ageing) }\end{array}$ & \multicolumn{21}{|c|}{ Geymsla í vatni og hita/kæli meðferð $5000 \mathrm{X}$ milli 5 and $55^{\circ} \mathrm{C}$, samtals 14 dagar } \\
\hline $\begin{array}{l}\text { Yfirborðs- } \\
\text { meðferð } 1\end{array}$ & \multicolumn{20}{|c|}{ Slípað með silikon karbíð sandpappír \#320 } & \\
\hline $\begin{array}{l}\text { Hreinsun } \\
\text { yfirborðs }\end{array}$ & \multicolumn{20}{|c|}{ Sýruæting (37\% fosforsýru gel í 15 sek) + skolun með vatni (15 sek) } & \\
\hline $\begin{array}{l}\text { Yfirborðs- } \\
\text { meðferð } 2\end{array}$ & \multicolumn{10}{|c|}{ Engin } & \multicolumn{10}{|c|}{ Bis-Sílan } & \\
\hline $\begin{array}{l}\text { Tannbeins } \\
\text { bindiefni }\end{array}$ & \multicolumn{2}{|c|}{$\begin{array}{l}\text { Scotchbond } \\
\text { MP }\end{array}$} & \multicolumn{2}{|c|}{$\begin{array}{l}\text { Scotchbond } \\
\text { MP } \\
\text { Bond only }\end{array}$} & \multicolumn{2}{|c|}{$\begin{array}{l}\text { Scotchbond } \\
\text { Univ. }\end{array}$} & \multicolumn{2}{|c|}{ Clearfil SE } & \multicolumn{2}{|c|}{$\begin{array}{l}\text { One Step } \\
\text { Plus }\end{array}$} & \multicolumn{2}{|c|}{$\begin{array}{l}\text { Scotchbond } \\
\text { MP }\end{array}$} & \multicolumn{2}{|c|}{$\begin{array}{l}\text { Scotchbond } \\
\text { MP } \\
\text { Bond only }\end{array}$} & \multicolumn{2}{|c|}{$\begin{array}{l}\text { Scotchbond } \\
\text { Univ. }\end{array}$} & \multicolumn{2}{|c|}{ Clearfil SE } & \multicolumn{2}{|c|}{$\begin{array}{l}\text { One Step } \\
\text { Plus }\end{array}$} & \\
\hline $\begin{array}{l}\text { Ljósherðing } \\
\text { bindiefnis* }\end{array}$ & $\mathrm{h}$ & óh & h & óh & h & óh & $\mathrm{h}$ & óh & h & óh & h & óh & $\mathrm{h}$ & óh & h & óh & h & óh & h & óh & \\
\hline $\begin{array}{c}\text { Nýtt } \\
\text { plastblendi }\end{array}$ & \multicolumn{20}{|c|}{ Filtek Supreme XLT litur A3,5B (10 × $6.2 \times 8$ mm) } & \\
\hline $\begin{array}{l}\text { Gömlun } \\
\text { (ageing) }\end{array}$ & \multicolumn{20}{|c|}{ Geymsla í vatni og hita/kæli meðferð $5000 X$ milli 5 and $55^{\circ} \mathrm{C}$, samtals 6 mánuði } & \\
\hline $\begin{array}{l}\text { Skurður } \\
\text { kubba }\end{array}$ & \multicolumn{20}{|c|}{ Skornir ferningslaga stautar $1.1 \times 1.1 \mathrm{~mm}$. } & \\
\hline Undirhópar & A1a & $\mathrm{A} 1 \mathrm{~b}$ & $\mathrm{~A} 2 \mathrm{a}$ & $\mathrm{A} 2 \mathrm{~b}$ & A3a & $\mathrm{A} 3 \mathrm{~b}$ & A4a & A4b & A5a & A5b & B1a & B1b & $\mathrm{B} 2 \mathrm{a}$ & $\mathrm{B} 2 \mathrm{~b}$ & $\mathrm{~B} 3 \mathrm{a}$ & $\mathrm{B} 3 \mathrm{~b}$ & B4a & B $4 b$ & B5a & $\mathrm{B} 5 \mathrm{~b}$ & C \\
\hline Fjöldi stauta & 51 & $\#$ & 57 & 56 & 65 & 61 & 60 & 61 & 66 & 60 & 63 & $\#$ & 65 & 62 & 65 & 61 & 61 & 67 & 62 & 66 & 66 \\
\hline
\end{tabular}

*) h: Bindiefni hert áður en gert er við með nýju plastblendi óh: Bindiefni ekki hert áđur en gert er við með nýju plastblendi

\#) I hópum A1b and B1b, biluðu allar límingar milli nýs og gamals plastblendis pegar kubbarnir voru fjarlægðir úr mótinu

\section{Efni og aðferðir}

Viðgerðarefni notuð í pessari rannsókn eru skráð í Töflu 1. Yfirlit yfir gerð, uppbyggingu og meðferð plastblendi kubba og prófunarstauta er sýnd í Töflu 2.

Áttatíu A1B Filtek Supreme XLT plastblendikubbar, $10 x$ $6,2 \mathrm{~mm}$. á breidd og $8 \mathrm{~mm}$. háir, voru byggðir upp í Teflon® móti samkvæmt fyrirmælum framleiðanda. Kubbarnir voru byggðir upp í fjórum lögum og hvert lag ljóshert í 40 sek. með Demetron A2 LED herðingarljósi sem var beintengt við rafmagn (Kerr Corp., Orange, CA. USA). Pegar kubbarnir höfðu verið fjarlægðir úr mótinu voru pær hliðar kubbanna sem mótið huldi einnig ljóshertar í 20 sek. Ljósmagn mældist $1100 \mathrm{~mW} / \mathrm{cm}^{2}$ (Norwegian Radiation Protection, Österaas, Norway). Fyrir viðmiðunarhóp voru 4 plastblendikubbar, 10 x 6,2 mm. á breidd en $12 \mathrm{~mm}$. háir, byggðir upp lagskipt á sama hátt.

Eftir ljósherðingu, voru allir plastblendikubbarnir strax settir í vatn og geymdir í tvær vikur $(26,27)$. Að auki voru kubbarnir gamlaðir (aged) í sjálfvirkri vél sem dýfði peim 5000 sinnum milli $5^{\circ} \mathrm{C} \mathrm{og} 55^{\circ} \mathrm{C}$ heitra vatnsbaða. Kubbarnir voru 20 sek. í hvoru vatnsbaði og færslutími 3 sek. á milli baða. Til að fá yfirborð með stöðluðum grófleika, voru kubbarnir 80 slípaðir á öđrum endanum undir rennandi vatni i 5 sek. á silikon karbíð sandpappírs diski með grófleika 320 (Struers, Copenhagen, Denmark). Slípað yfirborð allra plastblendikubbanna 80 var síðan hreinsað með pví að bera á með pensli 37\% fosfórsýru hlaup í 15 sek. sem var skolað burt með vatni í aðrar 15 sek.

Kubbunum 80 var skipt af handahófi í tvo jafnstóra tilraunahópa: A: sandpappírs slípað yfirborð og B: bis-Silane ${ }^{\mathrm{TM}}$, sem er tveggja pátta grunnur fyrir postulínslím borinn á slípað yfirborð. pættir A og B voru blandaðir og bornir á með pensli i 30 sek. og síðan purrkaðir varlega með lofti i 5-10 sek. Hópur C innihélt fjóra viðmiðunarkubba . Tilraunahópum A og B var síðan skipt upp í undirhópa sem fengu mismunandi tannbeinsbindiefni:

1. Adper Scotchbond Multi Purpose (3M ESPE), priggja prepa, æta og skola, bindiefni.

2. Adper Scotchbond Multi Purpose Adhesive (3M ESPE), par sem aðeins Adhesive bindiefnið var notað, en Primer grunninum sleppt. 
3. Adper Scotchbond Universal (3M ESPE), eins skrefa sjálfætandi bindiefni.

4. Clearfil SE (Kuraray America Inc, New York, NY), tveggja pátta sjálfætandi bindiefni.

5. One Step Plus (BISCO Inc, Schaumburg, IL), eins skrefa sjálfætandi bindiefni.

Öll meðferð og notkun tannbeinsbindiefna var samkvæmt leiðbeiningum framleiðenda við ísetningu plastblendifyllinga nema í hópum A2 og B2.

Hverjum tannbeins bindiefnahópi var skipt í tvennt: a og b. Í hópi a var bindiefni ljóshert samkvæmt ráđleggingum framleiðenda, en í hópi b var bindiefnið ekki hert áður en viðgerð fór fram með nýju plastblendi.

Eftir yfirborðsmeðferð og tannbeinsbindiefni hafði verið borið á, var upprunalega Teflon móti smeygt varlega yfir hvern plastblendikubb og fyrsta viðgerðar plastblendi laginu komið fyrir. Notað var Filtek Supreme XLT (3M ESPE), plastblendi, litur $A 3,5 B$, til að mögulega greina viðgerðarlínu við A1B lit gamlaða plastblendis. Til að tryggja sem besta aðlögun viðgerðarplastblendis, var efni sprautað á miðju kubbs sem átti að gera við, pví prýst niður og út til hliða með litlum flötum spaða. Næst var framlengingarmóti hagrætt ofaná upprunalegu Teflon® móti og gömluðu plastblendikubbarnir viðgerðir í premur tveggja mm. lögum á sama hátt og upprunalegu kubbarnir, pannig að 14 mm. plastblendikubbar fengust. Pegar kubbar í hópi b, óhert bindiefni, voru viðgerðir, var plastblendi einnig komið fyrir á miðju yfirborðs og pví prýst niður í bindiefnið og til hliðanna. Óharðnað bindiefni flæddi undan pykku plastblendinu til hliðanna og var fjarlægt áður en framlengingarmótinu var komið fyrir, til að hindra að bindiefni myndaði polla á skilum eða blandaðist inn í plastblendið. Viðgerðir kubbar voru hitaðir og kældir (thermal cycled) 5000 sinnum í sjálfvirkri vél milli $5^{\circ} \mathrm{C}$ og $55^{\circ} \mathrm{C}$ heitra vatnsbaða og síðan geymdir í eimuðu vatni i sex mánuði. Viðmiðunar plastblendikubbar (hópur C) voru einnig geymdir í vatni i sama tíma og hitaðir og kældir á sama hátt.

Plastblendikubbarnir voru festir í sjálfvirkra skurðarvél með punnu demantsblaði og vatnskælingu (Metcon®, Miracut 201 Automatic Precision Cutter, Bursa, Turkey). Kubbarnir voru skornir röð eftir röð, pvert á viðgerðarflötinn, bæði eftir x og y ás, pannig að fjöldi stauta með ferningslaga enda, u.p.b. 1,1 x 1,1 mm. fengust. U.p.b. 15 \pm 3 stautar fengust úr hverjum plastblendikubb. Tilraunarstautarnir voru næst hreinsaðir i úthljóðstæki i 3 mín. í eimuðu vatni. Eftir hreinsun var hver stautur skoðaður undir smásjá (American
Optical, Buffalo, NY, USA) í 40X stækkun í leit að bólum eða öðrum göllum í plastblendi og pykkt á bindiefnislagi mælt og skráð. Viðgerðarstyrkur var einungis mældur í gallalausum stautum. Breidd og pykkt á hverjum stauti var mæld og skráð næst tíunda úr mm. með lögvottuðum stafrænum pykktarmæli (Mitutoyo Co., Kawasaki, Japan).

Togpolsviðgerðarstyrkur var mældur með endurbættri aðferð við festingu tilraunastauta við bindistyrksmælitæki, sem tryggir beinna tog og jafnari dreifingu togkrafta eftir lengdarás stautsins. Stærð stautendanna, 1,1 mm. X 1,1 mm., var valin til að passa í skrúfugatsenda $2 \mathrm{~mm}$. tengiskrúfu, sem fást í venjulegum byggingavöruverslunum (ELRA AS, Oslo, Norway) (Mynd 1). Báðir endar hvers tilraunastauts voru límdir inn í skrúfuenda tengiskúfunnar með cyanoakrýl lími (Locktite 435, Henkel Norden, Gothenborg, Sweden). Sérstakt mót var útbúið til að tryggja réttan lengdarás skrúfa og tilraunastauts meðan lím harðnaði.

Hver stautur með skrúfum var festur í bindistyrksmælitækið (Loyd Instruments Ldt. Model LRX, Farham, England) með sérstökum vírum sem voru hannaðir til að færa beinan togkraft til viðgerðarflatar tilraunastauts. Mikro-togstyrkur var mældur á toghraða $1 \mathrm{~mm}$./min. pangað til stautur slitnar. Togpolsstyrkur hvers stauts var reiknaður út í megapaskölum (MPa) með pví að deila flatarmáli yfirborðs endaflatar i mm². í brotkraft mældan í Newtonum (N). Öllum tilraunastautum var haldið rökum allt rannsóknarferlið.

Brotfletir stauta voru skoðaðir í smásjá (American Optical, Buffalo, NY, USA) í 40\% stækkun til að ákvarða hvort brotlína var við eða í bindiefni á viðgerðarsvæði (adhesive) eða í plastblendi (cohesive). Viðgerðarsvæði var skilgreint svæðið milli gamlaða plastblendisins sem gert var við og hins nýja.

Við tölfræðiútreikninga var marktækni á mun viðgerðarstyrks milli yfirborðsmeðferða og tegunda bindiefna reiknuð í Microsoft Excel (Microsoft Corp., Redmond, WA, USA) skv. tillögum í ISO/TS 11405:2015 staðals um meðferð niðurstaðna á rannsóknum á bindistyrk (27). Litið var á að um marktækan mun væri að ræða ef $p<0,05 \%$.

\section{Niðurstöður}

Niðurstöður eru sýndar í Töflum 3 - 6. Öll viðgerð plastblendikubba í hópum A1b og B1b, Adper Scotchbond Multi-Purpose, óhert, biluðu í bindilagi pegar peir voru fjarlægðir úr Teflon® mótinu. 
Tafla 3. Niðurstöður míkró-togpolsprófa hjá undirhópum mismunandi tannbeinsbindiefna.

\begin{tabular}{|c|c|c|c|c|c|c|c|c|c|c|c|c|c|c|c|c|c|c|c|c|c|}
\hline Aðal hópar & & & & A. Silik & con ka & íð sandp & dpappír & & & & & & B. Si & ikon ka & rrbíd sanc & idpappí & $r+$ Bis-s & sílan & & & $\begin{array}{c}\text { C. } \\
\text { Viðmið }\end{array}$ \\
\hline $\begin{array}{l}\text { Tannbeins- } \\
\text { bindiefni }\end{array}$ & Scotc & $\begin{array}{l}\text { bond } \\
P\end{array}$ & $\begin{array}{r}\text { Scotc } \\
N \\
\text { Bond }\end{array}$ & $\begin{array}{l}\text { hbond } \\
\text { IP } \\
\text { d only }\end{array}$ & & & Cleart & fil SE & One & ep Plu & Scotchbo & nd MP & $\begin{array}{r}\text { Scotchb } \\
\text { Bond }\end{array}$ & $\begin{array}{l}\text { d MP } \\
\text { nly }\end{array}$ & $\begin{array}{l}\text { Scotchb } \\
\text { Unive }\end{array}$ & $\begin{array}{l}\text { bbond } \\
\text { ersal }\end{array}$ & Clear & fil SE & One Ste & tep Plus & \\
\hline Ljósherðing* & $h$ & óh & $h$ & óh & $\mathrm{h}$ & óh & $\mathrm{h}$ & óh & $h$ & óh & $\mathrm{h}$ & óh & $\mathrm{h}$ & óh & $\mathrm{h}$ & óh & $h$ & óh & $\mathrm{h}$ & óh & \\
\hline Undirhópar & A1a & $A 1 b$ & A2a & $A 2 b$ & A3a & A3b & A4a & $A 4 b$ & A5a & A5b & B1a & B1b & B2a & $\mathrm{B} 2 \mathrm{~b}$ & B3a & B3b & B4a & $B 4 b$ & B5a & $B 5 b$ & $C$ \\
\hline $\begin{array}{c}\text { Meðal } \\
\text { togbindi- } \\
\text { styrkur (SD) }\end{array}$ & $\begin{array}{l}27,8 \\
(4,04)\end{array}$ & $\#$ & $\begin{array}{l}29,9 \\
(4,47)\end{array}$ & $\begin{array}{c}33,1 \\
(4,20)\end{array}$ & $\begin{array}{r}33,1 \\
(8,55\end{array}$ & $\begin{array}{c}38,4 \\
(5,56)\end{array}$ & \begin{tabular}{|c|}
33,4 \\
$(6.00)$
\end{tabular} & $\begin{array}{c}38,5 \\
(6,70)\end{array}$ & $\begin{array}{r}33,9 \\
(7.25)\end{array}$ & $\begin{array}{l}36,8 \\
(6,8)\end{array}$ & $\begin{array}{c}33,0 \\
(5,65)\end{array}$ & \# & $\begin{array}{c}42,8 \\
(5,63)\end{array}$ & $\begin{array}{c}45,0 \\
(7,42)\end{array}$ & \begin{tabular}{|c|}
51,3 \\
$(9,57)$
\end{tabular} & $\begin{array}{c}55,0 \\
(8,71)\end{array}$ & \begin{tabular}{|c|}
49,4 \\
$(8,30)$
\end{tabular} & $\begin{array}{c}53,7 \\
(9,10)\end{array}$ & $\begin{array}{c}49,5 \\
(8,17)\end{array}$ & $\mid \begin{array}{c}55,1 \\
(10,12)\end{array}$ & $\begin{array}{c}62,2 \\
(5,29)\end{array}$ \\
\hline $\begin{array}{c}\text { Togbindi- } \\
\text { styrkur i \% af } \\
\text { við̈mið̇i a } \\
\end{array}$ & 44,7 & & 48,0 & 53,2 & 53,2 & 61,7 & 53,6 & 61,9 & 54,5 & 59,2 & 53,1 & & 68,8 & 72,3 & 72,3 & 88,4 & \begin{tabular}{|l|}
79,4 \\
\end{tabular} & 86,3 & 79,6 & 88,6 & 100 \\
\hline $\begin{array}{c}\% \text { brot í } \\
\text { plastblendi § }\end{array}$ & 0 & & 0 & 0 & 4 & 6 & 6 & 7 & 5 & 7 & 0 & & 3 & 7 & 11 & 13 & 13 & 19 & 14 & 19 & \\
\hline
\end{tabular}

*) $\quad$ : Bindiefni hert áður en viðgert var með nýju plastblendi

óh: Bindiefni óhert pegar gert var við með nýju plastblendi

‡) Meðaltals míkró-togbindistyrkur i MPa (SD meðalfrávik)

a) Prósent af mikró-togbindistyrk i MPa af viðmiðs sýnum (control)

§) Prósent af sýnum sem brotnuðu i plastblendi (cohesive)

\#) I hópum A1b and B1b slitnuðu allir plastblendi kubbarnir í bindiefnis línunni pegar peir voru losaðir úr mótinu

Tafla 4. Hópur A, Slípað með silikon karbið sandpappír. Niðurstöður tölfræðilegra útreikninga á muninum milli undirhópa.

\begin{tabular}{|c|c|c|c|c|c|c|c|c|}
\hline $\mathrm{A} 2 \mathrm{a}$ & $A 2 b$ & $\mathrm{~A} 3 \mathrm{a}$ & $A 3 b$ & $\mathrm{~A} 4 \mathrm{a}$ & $A 4 b$ & $\mathrm{~A} 5 \mathrm{a}$ & $A 5 b$ & \\
\hline \multirow[t]{9}{*}{ * } & $* * *$ & *** & $* * *$ & $* * *$ & $* * *$ & $* * *$ & $* * *$ & Ala \\
\hline & $* * *$ & $* *$ & $* * *$ & $* * *$ & $* * *$ & $* * *$ & $* * *$ & $\mathrm{~A} 2 \mathrm{a}$ \\
\hline & & ns & $* * *$ & ns & $* * *$ & ns & $* * *$ & $A 2 b$ \\
\hline & & & $* * *$ & ns & $\star * *$ & ns & $\star *$ & $\mathrm{~A} 3 \mathrm{a}$ \\
\hline & & & & $* * *$ & ns & $* * *$ & ns & $\mathrm{A} 3 \mathrm{~b}$ \\
\hline & & & & & $\star * *$ & ns & ns & $\mathrm{A} 4 \mathrm{a}$ \\
\hline & & & & & & $* * *$ & ns & $\mathrm{A} 4 \mathrm{~b}$ \\
\hline & & & & & & & * & $\mathrm{A} 5 \mathrm{a}$ \\
\hline & & & & & & & & $A 5 b$ \\
\hline
\end{tabular}

${ }^{*}=p<0.05,{ }^{* *}=p<0.01,{ }^{* * *}=p<0.001, n s=p>0.5$

Tafla 5 . Hópur B, Slipað með silikon karbið sandpappír + bis-silan. Niðurstöður tölfræðilegra útreikninga á muninum milli undirhópa.

\begin{tabular}{|c|c|c|c|c|c|c|c|c|}
\hline B2a & B2b & B3a & B3b & B4a & B4b & В5a & B5b & \\
\hline \multirow[t]{9}{*}{$* * *$} & $* * *$ & $* * *$ & $* * *$ & $* * *$ & $* * *$ & $* * *$ & $* * *$ & B1a \\
\hline & ns & $* * *$ & $* * *$ & $* * *$ & $\star * *$ & $* * *$ & $* * *$ & B2a \\
\hline & & $\star * *$ & $* * *$ & $* *$ & $* * *$ & ** & $* * *$ & $\mathrm{~B} 2 \mathrm{~b}$ \\
\hline & & & * & ns & ns & ns & * & $\mathrm{B3a}$ \\
\hline & & & & $* * *$ & ns & $\star * *$ & ns & B3b \\
\hline & & & & & $* *$ & ns & $* * *$ & B4a \\
\hline & & & & & & ** & ns & $B 4 b$ \\
\hline & & & & & & & $* * *$ & B5a \\
\hline & & & & & & & & B5b \\
\hline
\end{tabular}

${ }^{*}=p<0.05,{ }^{* *}=p<0.01,{ }^{* * *}=p<0.001, n s=p>0.05$ 
Tafla 6. Ekki silan á móti silan. Niðurstöður tölfræðilegra útreikninga á mun milli undirhópa.

\begin{tabular}{|c|c|}
\hline Samanburdur & P gildi \\
\hline$A 1 a / B 1 a$ & $P<0.001$ \\
\hline$A 2 a / B 2 a$ & $P<0.001$ \\
\hline$A 2 b / B 2 b$ & $P<0.001$ \\
\hline$A 3 a / B 3 a$ & $P<0.001$ \\
\hline$A 3 b / B 3 b$ & $P<0.001$ \\
\hline$A 4 a / B 4 a$ & $P<0.001$ \\
\hline$A 4 b / B 4 b$ & $P<0.001$ \\
\hline$A 5 a / B 5 a$ & $P<0.001$ \\
\hline$A 5 b / B 5 b$ & $P<0.001$ \\
\hline
\end{tabular}

Alls fengust 51-66 nothæfir stautar fyrir hvern undirhóp, eða samtals 1179. Meðal togstyrkur samanburðar plastblendistauta var 62,2 \pm 5,29 MPa. Hæsti meðal togstyrkur í viðgerðahópum var í hópi B5b, One Step Plus, bindiefni óhert $(55,1 \pm 10,12)$, og B3b, Scotchbond Universal, óhert $(55,0 \mathrm{MPa} \pm 8,71)$ og litlu minna í hópi B4b, Clearfil SE, bindiefni óhert. $(53,7 \mathrm{MPa} \pm 9,10)$, allir með sandpappír + bis-silan yfirborðsmeðferð. Viðgerðarstyrkur nemur í sömu röð $88,6 \%, 88,4 \%$ og $86,3 \%$ af styrk samanburðar plastblendis. Ekki var tölfræðilega marktækur munur milli pessara priggja hópa $(p>0,05)$. Meðalstyrkur viðmiðunar plastblendis var hins vegar marktækt meiri en sterkasti viðgerðarstyrkurinn $(p<0.001)$. Viðgerðarhópur með Iægsta meðal togstyrk var hópur A1a, Adper Scotchbond MultiPurpose, silikon sandpappír + bindiefni hert, $(27,8 \mathrm{MPa}$ $\pm 4,04$ ). Petta nemur aðeins $44,7 \%$ af styrk viðmiðunar plastblendisins.

Með pví að herða ekki bindiefni áđur en nýju plastblendi er bætt á gamlað plastblendi, jókst bindistyrkur marktækt hjá öllum tegundum bindiefna nema hjá hópi B2, Adper Scotchbond Multi-Purpose Adhesive. Hjä öllum bindiefnum í A hópi, slípað með sandpappír, var munur mjög marktækur $(p<0,001)$. Í hópi $B$, slípað með silikon sandpappír + bis-sílan, var munurinn mjög marktækur hjá One step Plus $(p<0,001)$ meðan marktæknin var nokkuð minni hjá Clearfil SE $(p<0,01)$ og Adper Scotchbond Universal $(p<0,05)$. Auk pessa, jók bis-sílan meðferð eftir slípun með silikon karbíð sandpappír marktækt míkró-togpolsstyrk hjá öllum bindiefnum, bæði í hertu og óhertu hópunum. Undantekning frá pessu er Adper Scotchbond MultiPurpose óhert, bæði með og án bis-sílans (hópar A1b og B1b), par sem allir kubbar slitnuðu sundur pegar peir voru fjarlægðir úr Teflon® móti.

pykkt á hertu bindilagi mældist $5 \mu \mathrm{m}$. hjá Clearfil SE

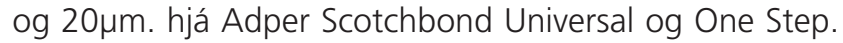
pykktin á hertu bindilagi hjá Adper Scotchbond MultiPurpose með og án grunns (Primer) var mispykkari en hjá

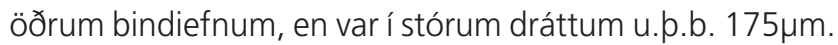
Í hópum par sem bindiefni var óhert við viðgerð, virtist nýja plastblendið vera pétt við pað gamlaða, pannig að bindiefnislína sást varla eða ekki undir smásjá.

Hlutfall stauta sem brotnuðu í plastblendi (cohesive) er sýnt í Töflu 2. Öll brotin í plastblendi voru í gamlaða plastblendinu. Brot í plastblendi voru helst í viðgerðarhópum sem höfðu hæstan viðgerðarstyrk. Flest brot í plastblendi voru í hópum B4b og B5b (19\%), sem eru hópar sem sýndu hæstan viðgerðarstyrk. Í hópi A, slípað með silikon sandpappír, slitnuðu allir eða nánast allir stautar í límingu pegar Adper Scotchbond Multi-Purpose var notað.

\section{Umræða}

Pað hefur sýnt sig að tannlæknar kjósa að nota sömu aðferðir við að setja í fyllingar og gera við pær. Notkun demantsbora til að fjarlægja gallaða hlutann, sýruæting og tannbeinsbindiefni á yfirborð virðist vera algengasti undirbúningur á gamalli plastblendifyllingu sem gera skal við (5). Petta er líka algengasta aðferð sem kennd er við flesta tannlæknaskóla $(2,3,23,28)$.

I pessari rannsókn er metin sú tilgáta að pví pynnra sem bindilagið milli gamla og nýja plastblendisins er, peim mun sterkari verðu binding, eins og fjallað er um í niðurstöðum fyrri rannsóknar höfunda (13). Par sem líklegt er talið að bindiefnislagið sé veikasti hlekkur í viðgerðri fyllingu, má ætla að við pað að pynna petta lag verði gamla og nýja plastblendið næstum ein eining, líkt og lagt hefur verið til um límingu tannbrota við tennur (29). Með pví að prýsta nýju plastblendi inn í óharðnað bindiefnið, er hægt að segja að bindiefni verki sem bleytiefni sem fylli einungis hrufur í yfirborðinu. Niðurstöður pessarar rannsóknar sýna fram á marktæka aukningu í bindistyrk hjá öllum tannbeinsbindiefnahópum pegar bindiefnið er ekki hert áður en viðgerðarefni er komið fyrir, bæði með og án bis-sílan meðferðar, nema hjá Filtek Scotchbond Multi-Purpose, priggja skrefa (Tafla 3). Við smásjárskoðun var bindilagið ekki sýnilegt hjá neinum hópi par sem bindiefni var ekki hert, sem bendir til mikillar nálægðar milli nýja og gamla plastblendis.

Allir plastblendiskubbar úr hópum A1b og B1b, Adper Scotchbond Multi-Purpose óhert, mistókust og slitnuðu pegar verið var að fjarlægja kubba úr móti. Bindiefnið er í hópi peirra efna sem hafa gegnum árin gefið mjög góða raun og sýnt ágætan árangur í klínískum rannsóknum á jaxlafyllingum úr plastblendi (30). Bilunin varð i límlagi sem 
virtist ekki hafa hvarfast almennilega. Höfundar telja að viðgerðarplastblendið hafi prýst bindiefninu burt, pannig að plastblendið hafi verið í beinni snertingu við grunninn (primer). pví hafi myndast ammóníum úr acrýlsýru- og ítonsýruhópum úr samfjölliðungum (copolymer) í grunninum, sem hafi gert tertíer amín í ljósherðingarhvatakerfi viðgerðarplastbendis óvirkt og pannig hindrað fjölliðun pess í snertingu við grunninn $(31,32)$.

Nauðsynlegt er að fjarlægja örlítið af yfirborði gamals plastblendis með demantsbor til að hreinsa og gera yfirborðið hrjúft, og par með skapa aukna festu með míkro-undirskurði i hrufum. I in-vitro rannsóknum á viðgerð plastblendifyllinga fæst staðlað yfirborð með pví að slípa yfirborð með silikonkarbíð sandpappír sem líkir eftir grófleika á miðlungs grófum demantsbor. Með forrannsókn kom í ljós að með Profilometer að sandpappír nr. 320 gaf svipaðan grófleika og miðlungsgrófur bor. Tannbeinsbindiefni sem voru valin til rannsóknar eru pekkt bindiefni á markaði í dag. Adper Scotchbond Multi-Purpose er priggja skrefa æta og skola kerfi og Clearfil SE tveggja skrefa sjálfætandi kerfi, bæði með vatnsbundnum grunni. Adper Scotchbond Universal er vatns/etanól bundið meðan One Step er vatns/ asetón bundið; bæði sjálfætandi einnar flösku kerfi. Adper Scotchbond Universal inniheldur einnig lítið magn af sílan. Sjálfætandi bindiefnin prjú gáfu gegnum sneitt hærri viðgerðarstyrk en Filtek Multi-Purpose. prátt fyrir töluverðan mun í samsetningu einliðunga og leysiefna, gáfu öll prjú sjálfætandi bindiefnin svipaðar niðurstöður í bindistyrk. Í nýlegri rannsókn á bindistyrk með pverklippiaðferð (shear testing) gaf Filtek Scotchbond Universal, sem inniheldur örlítið sílan, svipaðan viðgerðarstyrk og Clearfil SE, par sem bis-sílan hafði verið borið áður á plastblendið (17). Sú niðurstaða er í andstöðu við okkar niðurstöður, par sem bæði efni gáfu svipaðan bindistyrk, með og án bis-sílan.

Sílan eykur bindistyrk við kísiltengd efni (33). Rannsóknir á notkun sílan við viðgerðir plastblendis hafa verið misvísandi, en niðurstöður sýna að sílan auki, minnki eða hafi engin áhrif á viðgerðarstyrk $(13,17,20,21,33-35)$.

Í fyrri rannsókn höfunda fékkst besti viðgerðarstyrkur með slípun með silikonkarbíð sandpappír, sílan meðferð, auk bindiefnis sem gaf punnt bindilag (13). Sílanmeðferð er einföld og örugg aðgerð sem krefst ekki sérstakra tækja eða tóla. Í pessari rannsókn jók sílanmeðferð marktækt $\mu$-togpolsstyrk hjá öllum bindiefnum og herðingaraðferðum (Tafla 6). Sílan eitt og sér getur ekki komið í stað tannbeinsbindiefnis sem bleytiefni sem fyllir upp í hrufur og bólur á yfirborði plastblendis (23). Sílan er fyrst og fremst tengimiðill sem eykur viðloðun og bindingu (36).
I flestum rannsóknum sem meta áhrif sílans á bindistyrk, er einnar flösku for-vatnsrofið (pre-hydrolized) efni notað $(12,20,21,34,35,37)$. Eftir opnun flösku hefur efnið lítið geymslupol og gæti innan nokkurs tíma orðið gruggugt og tapað eiginleikum sínum. Í pessari rannsókn var notað tveggja flösku kerfi par sem óvatnsrofið sílan í etanóli er í annarri flöskunni og ediksýra í hinni (33). Með pví að blanda vökvunum saman hefst vatnsrof (hydolysis) sílans og fersk blanda er tilbúin til notkunar. Notkun tveggja flösku kerfis tryggir ávalt ferska blöndu af sílani og lengir líftíma pess verulega. Lundvall et al. mældu marktækt hærri bindistyrk við postulínsviðgerð með plastblendi pegar tveggja pátta bis-sílan var notað, meðan hópurinn sem fékk einnar flösku sílan og hópurinn sem var án sílans gáfu svipaðan bindistyrk (38). Graiff et al. fundu að binding milli plastsements til að festa krónur og tannbeins minnkaði ekki pótt sílan færi á tannbeinið (39).

Möguleikinn að fá efnatengi við plastblendi minnkar hægt og sígandi með tímanum vegna eftir-hvörfunar (post-curing) og vatnsupptöku sem leiðir til niðurbrots tvíbindinga, pannig að karboxýl hópum sem geta hvarfast við nýtt plastblendi fækkar $(8,9,40)$. Við in-vitro rannsóknir á viðgerðar bindistyrk er mikilvægt að geyma plastblendisýni og hraða öldrun peirra með geymslu í vatni nógu lengi auk hita/kæli meðferðar (thermal cycling), til að eiga möguleika á að fá martækar niðurstöður. Nýleg samantekt á slíkum rannsóknum gefur til kynna að oft sé mjög stuttur tími frá pví að grunnsýni eru búin til, pau viðgerð og bindistyrkur mældur (37). I 88\% rannsókna var plastblendið sem líma átti við einungis gamlað með geymslu í vatni, og í 44\% rannsókna einungis í 48 klst. eða minna, án nokkurrar annarrar gömlunar eins og hita/ kæli meðferðar. Svo stuttur geymslutími leiðir til ofmats á bindistyrk og gerir samanburð á áhrifum yfirborðsmeðferða ómarkvissan. Hjá sex mismunandi plastblendisýnum sem voru geymd í vatni í nokkra daga mældust 25\% - 48\% metakrýl hópa óhvarfaðir (41). Sýnt hefur verið fram á að við purrar aðstæður fer viðgerðarstyrkur ekki að lækka fyrr en plastblendið hefur verið geymt í 14 daga (25). pað kom pví á óvart að í nýlegri kerfisbundinni greiningu (meta analysis) á rannsóknum á viðgerðarstyrk, voru kröfur höfunda um hæfi rannsóknar einungis 24 tíma geymsla í vatni á viðgerðum plastblendikubbum (37). Önnur skrýtin krafa í samantektinni var um viðmiðunarhóp, sem væri annaðhvort með ómeðhöndlað yfirborð eða slípað með demanti eða sandpappír án nokkurs bindilags. Við viðgerð á gömlu plastblendi koma bæði pessi yfirborð aldrei til greina klínískt og pjóna pví ekki sem viðmið. Í rannsóknum 
á plastblendi á tilraunastofum er ómeðhöndlað yfirborð oftast pað sem fæst undan Mylar'M matrixu bandi, par sem einungis resin er á yfirborðinu. Pegar gert er við plastblendi er yfirborðið nánast altaf pað sem fæst eftir demantsbor, og pá er helmingur yfirborðsins slípuð fyllikorn og hinn hluti plastefni. Við klínískar aðstæður er hluti af viðgerð oftast líka í snertingu við tannvef, pannig að í öllum tilfellum er notkun bindiefnis nauðsynleg. Í pessari rannsókn var ákváđið að nota sem viðmið mesta hugsanlega viðgerðarstyrkleika og togstyrkleika plastblendis sem var gamlað eins og viðgerðakubbarnir. pað er óraunhæft að styrkleiki nýs plastblendis náist, par sem plastblendi tapar styrk með tímanum (13). Meðan ekki er neinn staðall eða samkomulag meðal rannsakenda hvernig og hve lengi skuli gamla plastblendi, telja höfundar að samanburður milli rannsókna verði raunhæfari pegar togstyrkur jafn gamlaðs plastblendis og er í viðgerðarkubbum er notað sem viðmið (control).

Undirbúningur og tilbúningur stauta og framkvæmd $\mu$-togpolspprófa er mikilvægur til að fá réttar niðurstöður, pví sýnt hefur verið fram á að brot á prófunarstautnum geta verið háð framkvæmdinni (42). Viðgerðarstyrkur er sá kraftur sem parf til að prófunarstauturinn brotni. Ef mörg eða meirihluti sýna brotna í plastblendinu, gefur pað litla hugmynd um hinn eiginlega viðgerðarstyrk. pað hefur pví miður verið raunin í mörgum rannsóknum $(15,20,21,34,47,48)$. Pannig var pað í nýlegri rannsókn par sem yfir 90\% sýna brotnuðu i plastblendinu og höfundarnir ályktuðu að sílan bætti ekki viðgerðarstyrk (20). Svona yfirlýsingar eru vægast sagt mjög villandi og byggðar á rangtúlkun á niðurstöðum.

Í nýlegri yfirlitsgrein kom fram að af öllum rannsóknum á viðgerðarstyrk plastblendis notuðu 60\% rannsóknaraðila pverklippi (shear testing) aðferð við styrkmælingar (37). Margir höfundar hafa gagnrýnt pessa aðferð par sem hún valdi streitupéttni (stress concentration) í gamlaða og nýja plastblendinu, sem valdi pví að brotið verði fremur par en í bindiefnislaginu $(26,43)$. Heintze ráðlagði að hætt yrði að nota pverklippi aðferð vegna ófullnægjandi og ójafnrar streitudreifingar og lítillar fylgni við klíniskar niðurstöður (44). Pessi gagnrýni hefur leitt til aukinnar notkunar á $\mu$-togpolsprófi, sem krefst miklu meiri vinnu og tíma, en er talin dreifa streitu betur um prófunarstautana og beina togkraftinum pannig að streitupéttnin verði mest í límingunni sem verið er að prófa $(45,46)$. Eliasson et al. (13) próaði og kynnti endurbætt $\mu$-togpolspróf sem er mun fljótlegra og auðveldara i framkvæmd, par sem prófunarstautar eru límdir inn í hola enda $2 \mathrm{~mm}$. tengiskrúfu sem eru tengdir við sérútbúna langa víra sem eru festir við togpolsmælitækið, pannig að prófunarstautur liggur örugglega í beinni línu. Togkraftar sem beinast frá endum stauta gera pað að verkum að kraftar dreifast jafnar og langsum eftir prófunarstautum. pað að langflestir stautar brotna í viðgerðarmótum styður pessa kenningu og niðurstöður pví líklegri til að vera réttar. Samkvæmt niðurstöðum pessarar rannsóknar er öllum premur rannsóknartilgátum hafnað.

\section{Ályktun}

Pessi rannsókn staðfestir fyrri niðurstöđur höfunda, par sem besta mikro-togstyrk er náð með pví að nota nýblandað sílan og bindiefni sem gefur punnt bindilag. Enn betri viðgerðarstyrkur fæst með aukinni nálægð á nýju og gömlu plastblendi, sem fæst með pví að herða ekki bindiefnið áđur en viðgerð fer fram. Viðgerðir á plastblendi verða pannig einfaldari og fljótlegri.

\section{Hagsmunaárekstrar}

Höfundar pessarar greinar votta að engin hagsmunatengs| eru við framleiðendur efna né tækja sem voru notuð við pessa rannsókn og að öll efni voru keypt á markaðsverði.

Grein pessi er að hluta byggð a grein höfunda: Effect of curing and silanizing on composite repair bond strength using an improved micro-tensile test method i Acta Biomater Odontol Scand. 2017;3(1):21-29.

\section{Heimildir}

1. Krejci I, Lieber CM, Lutz F. Time required to remove totally bonded tooth-colored posterior restorations and related tooth substance loss. Dent Mater. 1995;11(1):34-40.

2. Blum IR, Lynch CD, Wilson NH. Teaching of direct composite restoration repair in undergraduate dental schools in the United Kingdom and Ireland. Eur J Dent Educ. 2012;16(1):e53-8.

3. Blum IR, Lynch CD, Wilson NH. Teaching of the repair of defective composite restorations in Scandinavian dental schools. J Oral Rehabil. 2012;39(3):210-6.

4. Lynch $C D$, Blum IR, Frazier KB, et al. Repair or replacement of defective direct resin-based composite restorations: contemporary teaching in U.S. and Canadian dental schools. J Am Dent Assoc. 2012;143(2):157-63.

5. Staxrud F, Tveit AB, Rukke HV, et al. Repair of defective composite restorations. A questionnaire study among dentists in the Public Dental Service in Norway. J. Dent. 2016;52:50-54.

6. Brosh $\mathrm{T}$, Baharav $\mathrm{H}$, Gross $\mathrm{O}$, et al. The influence of surface loading and irradiation time during curing on mechanical properties of a composite. J Prosthet Dent 1997;77(6):573-7.

7. Malacarne J, Carvalho RM, de Goes MF, et al. Water sorption/solubility of dental adhesive resins. Dent Mater. 2006;22(10):973-80.

8. Lagouvardos PE, Pissis P, Kyritsis A, et al. Water sorption and water-induced molecular mobility in dental composite resins. J Mater Sci Mater Med. 2003;14(9):7539.

9. Tarumi H, Torii M, Tsuchitani Y. Relationship between particle size of barium glass filler and water sorption of light-cured composite resin. Dent Mater J. 1995;14(1):3744.

10. Gordan VV, Garvan CW, Blaser PK, et al. A long-term evaluation of alternative treatments to replacement of resin-based composite restorations Results of a sevenyear study. J Am Dent Assoc. 2009;140(12):1476-84. 
11. Fernandez EM, Martin JA, Angel PA, et al. Survival rate of sealed, refurbished and repaired defective restorations: 4-year follow-up. Braz Dent J. 2011;22(2):134-9.

12. Ozcan M, Koc-Dundar B. J Adhes Sci Technol. 2014;28(21):2209-29.

13. Eliasson ST, Tibballs J, Dahl JE. Effect of different surface treatments and adhesives on repair bond strength of resin composites after one and 12 months of storage using an improved microtensile test method. Oper Dent. 2014;39(5):E206-16.

14. Hamano N, Chiang YC, Nyamaa I, et al. Effect of different surface treatments on the repair strength of a nanofilled resin-based composite. Dent Mater J. 2011;30(4):53745.

15. Maneenut C, Sakoolnamarka R, Tyas MJ. The repair potential of resin composite materials. Dent Mater. 2011;27(2):e20-e27.

16. Özcan M, Barbosa SH, Melo RM, et al. Effect of surface conditioning methods on the microtensile bond strength of resin composite to composite after aging conditions. Dent Mater. 2007;23(10):1276-82.

17. Staxrud F, Dahl JE. Silanising agents promote resin-composite repair. Int Dent J. 2015;65(6):311-15.

18. Imbery TA, Gray T, DeLatour F, et al. Evaluation of flexural, diametral tensile, and shear bond strength of composite repairs. Oper Dent. 2014;39(6):E250-60.

19. Tantbirojn $D$, Fernando $C$, Versluis A. Failure Strengths of Composite Additions and Repairs. Oper Dent. 2015;40(4):364-71.

20. Cho SD, Rajitrangson P, Matis BA, et al. Effect of Er,Cr:YSGG laser, air abrasion, and silane application on repaired shear bond strength of composites. Oper Dent 2013;38(3):E1-9.

21. da Costa TRF, Serrano AM, Atman APF, et al. Durability of composite repair using different surface treatments. J Dent. 2012;40(6):513-21.

22. Ozcan M, Corazza PH, Marocho SMS, et al. Repair bond strength of microhybrid, nanohybrid and nanofilled resin composites: effect of substrate resin type, surface conditioning and ageing. Clin Oral Investig. 2013;17(7):1751-58.

23. Barcellos DC, Santos VMM, Niu LN, et al. Repair of composites: Effect of laser and different surface treatments. Int J Adhes Adhes. 2015;59:1-6.

24. Coelho PG, Calamia C, Harsono M, et al. Laboratory and FEA evaluation of dentinto-composite bonding as a function adhesive layer thickness. Dent Mater. 2008;24(10):1297-303

25. Dall'Oca S, Papacchini F, Goracci C, et al. Effect of oxygen inhibition on composite repair strength over time. J Biomed Mater Res B Appl Biomater. 2007;81(2):493-8.

26. Van Noort R, Noroozi S, Howard IC, et al. A critique of bond strength measurements. J Dent. 1989;17(2):61-7.

27. ISO/TS 11405:2015, Dentistry - Testing of adhesion to tooth structure. 3rd. ed. ed. Geneva, Swittzerland: International Standard Organization.

28. Blum IR, Schriever A, Heidemann D, et al. The repair of direct composite restorations: an international survey of the teaching of operative techniques and materials. Eur $\mathrm{J}$ Dent Educ. 2003;7(1):41-8.

29. Lise DP, Vieira LCC, Araujo E, al. Tooth Fragment Reattachment: The Natural Restoration. Oper Dent. 2012;37(6):584-90.

30. Van Meerbeek B, De Munck J, Yoshida Y, et al. Buonocore Memorial Lecture Adhesion to enamel and dentin: Current status and future challenges. Oper Dent. 2003;28(3):215-35.

31. IE. R. Monomer systems and polymerization. Utrect: Peter Szulc Publishing Co.; 1998.

32. Nie J, Linden LA, Rabek JF, et al. A reappraisal of the photopolymerization kinetics of triethyleneglycol dimethacrylate initiated by camphorquinone-N,N-dimethyl-ptoluidine for dental purposes. Acta Polym. 1998;49(4):145-61.

33. Lung CYK, Matinlinna JP. Aspects of silane coupling agents and surface conditioning in dentistry: An overview. Dent Mater. 2012;28(5):467-77.

34. Rodrigues SA, Jr., Ferracane JL, Della Bona A. Influence of surface treatments on the bond strength of repaired resin composite restorative materials. Dent Mater. 2009;25(4):442-51.

35. Bonstein T, Garlapo D, Donarummo J, Jr., et al. Evaluation of varied repair protocols applied to aged composite resin. J Adhes Dent. 2005;7(1):41-9.

36. Ozcan M, Matinlinna JP, Vallittu PK, al. Effect of drying time of 3-methacryloxypropyltrimethoxysilane on the shear bond strength of a composite resin to silica-coated base/noble alloys. Dent Mater. 2004;20(6):586-90.

37. Valente LL. S-OR, Concalves AP., Fernándes E., et al. Repair bond strength of dental composites: systemic review. Int J Adhes. and Adhes. 2016;69:15-26.
38. Lundvall PK, Ruyter E, Ronold HJ, et al. Comparison of Different Etching Agents and Repair Materials Used on Feldspathic Porcelain. J Adhes Sci Technol. 2009;23(78):1177-86.

39. Graiff L. PC, Vigolo, P., Mason PN. Shear bond strength between felspatc CAD/CAM ceramicand human dentine for two adhesive cements. J Prosthodont. 2008;17:2949 .

40. Burtscher P. Stability of Radicals in Cured Composite-Materials. Dent Mater. 1993;9(4):218-21.

41. Ruyter IE, Svendsen SA. Remaining Methacrylate Groups in Composite Restorative Materials. Acta Odontol Scand. 1978;36(2):75-82.

42. Gregory WA, Pounder B, Bakus E. Bond strengths of chemically dissimilar repaired composite resins. J Prosthet Dent. 1990;64(6):664-68.

43. Della Bona A, van Noort R. Shear vs. tensile bond strength of resin composite bonded to ceramic. J Dent Res. 1995;74(9):1591-6.

44. Heintze SD. Clinical relevance of tests on bond strength, microleakage and marginal adaptation. Dent Mater. 2013;29(1):59-84.

45. Scherrer SS, Cesar PF, Swain MV. Direct comparison of the bond strength results of the different test methods: A critical literature review. Dent Mater. 2010;26(2):E78E93.

46. Pashley DH, Carvalho RM, Sano $\mathrm{H}$, et al. The microtensile bond test: a review. J Adhes Dent. 1999;1(4):299-309.

47. Loomans BA, Cardoso MV, Roeters FJ, et al. Is there one optimal repair technique for all composites? Dent Mater. 2011;27(7):701-9.

48. Hamano N, Chiang YC, Nyamaa I, et al. Repair of silorane-based dental composites: Influence of surface treatments. Dent Mater. 2012;28(8):894-902. 


\title{
Effect of silanizing and light curing on composite repair strength
}

\author{
SIGFUS THOR ELIASSON, DDS, MSD, PROFESSOR EMERITUS, FACULTY OF ODONTOLOGY, UNIVERSITY OF \\ ICELAND, REYKJAVIK, ICELAND, VISITING SCIENTIST, NORDIC INSTITUTE OF DENTAL MATERIALS, OSLO, NORWAY \\ JON E. DAHL, DDS, DR ODONT DSC, DIRECTOR, NORDIC INSTITUTE OF DENTAL MATERIALS, OSLO, NORWAY, \\ PROFESSOR, SCHOOL OF DENTISTRY, UNIVERSITY OF OSLO, NORWAY
}

ICELANDIC DENT J 2021; 39(2): 12-21

doi: 10.33112/tann.39.2.1

Objectives: To evaluate the micro-tensile repair bond strength between aged and new composite, using silane and adhesives that were cured or left uncured when new composite was placed.

Methods: Eighty Filtek Supreme XLT composite blocks and four control blocks were stored in water for two weeks and thermocycled. Sandpaper ground, etched and rinsed specimens were divided into two experimental groups: A, no further treatment and B, the surface was coated with bis-silane. Each group was divided into subgroups: (1) Adper Scotchbond Multi-Purpose, (2) Adper Scotchbond Multi-Purpose adhesive, (3) Adper Scotchbond Universal, (4) Clearfil SE Bond and (5) One Step Plus. For each adhesive group, the adhesive was (a) cured according to manufacturer's instructions or (b) not cured before repair. The substrate blocks were repaired with Filtek Supreme XLT. After aging, they were serially sectioned, producing $1.1 \times 1.1 \mathrm{~mm}$ square test rods. The rods were prepared for tensile testing and tensile strength calculated at fracture. Type of fracture was examined under microscope.

Results: Leaving the adhesive uncured prior to composite repair placement increased the mean tensile values statistically significant for all adhesives tested, with or without silane pretreatment. Silane surface treatment improved significantly $(p<0.001)$ tensile strength values for all adhesives, both for the cured and uncured groups. The mean strength of the control composite was higher than the strongest repair strength $(p<0.001)$.

Conclusions: Application of freshly made silane and a thin bonding layer, rendered higher tensile bond strength. Not curing the adhesive before composite placement increased the tensile bond strength.

Keywords: Silane, adhesive, micro-tensil strength, composite Correspondence: Sigfus Pór Elíasson, e-mail: sigfuse@hi.is 